\title{
Corrigendum
}

\section{Ligand substitution of receptor targeted DNA complexes affects gene transfer into hepatoma cells}

Ziady et al

Gene Therapy 1998; 5: 1685-1697

In the above paper, Figure $3 \mathrm{c}$ is incorrect. The correct cropped version appears below. The authors apologise for this error.

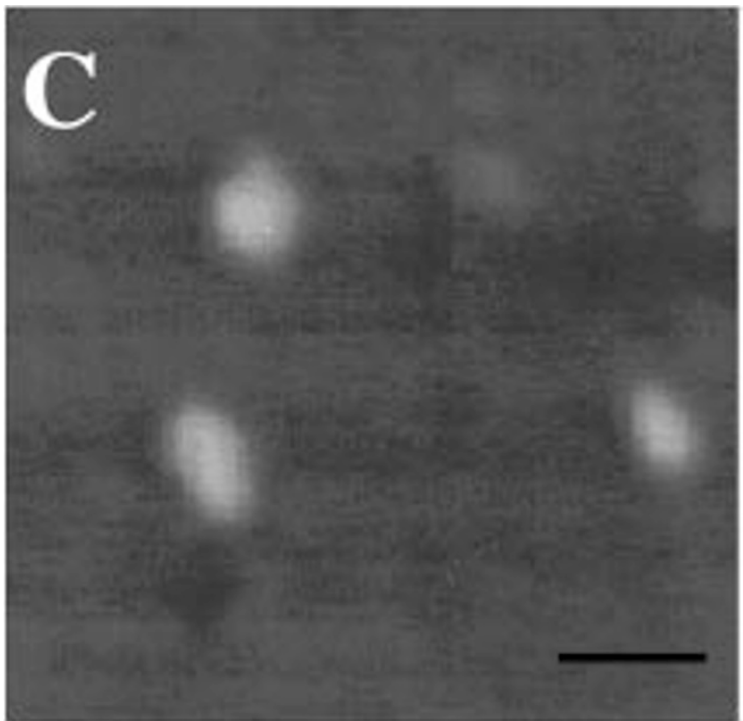

\section{Bar, $100 \mathrm{~nm}$}

Figure 3 Microscopic analysis of SEC-R ligand containing DNA complexes. Complexes formed used high salt conditions $(\sim 1 \mathrm{~m})$ were diluted 10 times and immediately pipetted on to a 1000-mesh electron microscope carbon grid (EM; $a, b)$ or on to $2 \mathrm{~cm} \times 2 \mathrm{~cm}$ Mica wafer (AFM). For AFM the preparations were either dried for $3 h$ (solid phase AFM; $c, d$ ) or immersed in water in a sealed chamber, incubated for $1 \mathrm{~h}$ (hydrated AFM; $e, f)$ and then scanned by a Nanoscope III atomic force microscope. For all photographs, the plasmid was SV40 pGL3 control $(5.22 \mathrm{~kb})$. The protein portion of the complex was: (c) $22.5 \mathrm{kDa}$ poly K containing $3.5 \%$ sulfo-LC SPDP and 0.017\% C105Y ligand. Bar, $100 \mathrm{~nm}$. 